\title{
CREATING EFFECTIVENESS OF NUTRITION POLICY IMPROVEMENT PROGRAM IN SUBANG REGENCY
}

\author{
Iwan Henri Kusnadi \\ Universitas Subang \\ Jl. R.A. Kartini Km. 3 Subang, 41285, West Java, Indonesia \\ Correspondence Email: iwanhenri@unsub.ac.id
}

Submitted: 10-07-2020, Reviewed: 29-09-2020, Accepted: 30-10-2020

\begin{abstract}
This study aimed to determine the effectiveness of the nutrition improvement program policy in Subang Regency. This study uses a qualitative descriptive research method through observation and interviews, literature study, and documentation. Data triangulation and obtained from key informants directly and relevant to the problem under study are sources of data. The results showed that the policy program for improving Subang Regency nutrition has been running but has not been effective, including several factors such as limited human resources who manage the program. The availability of additional food for infants and toddlers is still insufficient. For this reason, it needs to be considered so that the program can be carried out properly following the stated objectives. The government needs to pay more attention to the adequacy of nutrition workers. To provide maximum service to the community. The implementation of nutrition improvement programs must be more activated, maintained continuously, and improved communication and socialization, built both cross-program and cross-sectoral to reduce malnutrition cases. Procedures for handling cases of malnutrition. It is hoped that the procedure for referring children suffering from malnutrition can be faster so that children can be treated quickly, and their nutritional condition can quickly improve.
\end{abstract}

Keywords: Effectiveness, Policy Implementation, Food Security, Malnutrition

\begin{abstract}
ABSTRAK
Tujuan penelitian ini untuk mengetahui Efektivitas kebijakan program Perbaikan Gizi Di Kabupaten Subang. Dalam penelitian ini menggunakan metode penelitian deskriptif kualitatif, melalui observasi dan wawancara, studi kepustakaan dan dokumentasi. Sumber data dengan triangulasi data dan diperoleh dari informan-informan kunci secara langsung dan yang relevan dengan masalah yang diteliti. Hasil penelitian bahwa kebijakan program kebijakan perbaikan Gizi Di Kabupaten Subang telah berjalan tetapi belum efektif diantaranya beberapa faktor seperti sumber daya manusia yang mengelola program jumlahnya terbatas, ketersediaan makanan tambahan untuk bayi dan balita jumlahnya masih kurang. Untuk itu hal tersebut perlu diperhatikan agar program dapat terlaksana dengan baik sesuai dengan tujuan yang telah ditetapkan. Pemerintah perlu memperhatikan lagi kecukupan tenaga gizi. Agar bisa memberikan pelayanan yang maksimal kepada masyarakat. Pelaksanaan program perbaikan gizi harus lebih diaktifkan, terus dijaga, dan ditingkatkan komunikasi dan sosialisasi, dibinan dengan baik secara lintas program maupun lintas sektoral untuk mengurangi terjadinya kasus gizi buruk. prosedur penanganan kasus gizi buruk. Diharapkan prosedur merujuk anak yang menderita gizi buruk dapat lebih cepat, sehingga anak dapat ditangani dengan cepat dan kondisi gizinya lekas membaik.
\end{abstract}

Kata Kunci: Efektivitas, Implementasi Kebijakan, Ketahanan Pangan, Gizi Buruk

\section{BACKGROUND}

The success of a nation's development is determined by the availability of quality human resources
(HR), namely human resources who have a healthy physical, strong mental, excellent health, and smart brain. Empirical evidence shows that a good nutritional status largely 
Vol.6, No.2, 2020

Doi: https://doi.org/10.24198/cosmogov.v6i2.28541

http://jurnal.unpad.ac.id/cosmogov/index

determines this, and good nutritional status is determined by the amount of food consumed. Malnutrition and malnutrition are directly affected by food consumption and infectious diseases. Indirectly influenced by parenting styles, food availability, socio-economic factors, and influenced by culture and politics. Undernutrition in infants and toddlers that are not handled quickly will lead to a state of malnutrition which can cause physical growth disorders including the brain which can affect intelligence and cause developmental disorders, which will contribute to the low quality of human resources in the future. Come, they will even be the cause of the loss of generations that affect the nation's progress and state.

Health is one of the most important assets in development. Efforts to improve public health are one of the main goals of all nations in the world. In a global agreement known as the Millennium Development Goals (MDGs), health has received a great deal of attention. The problem of improving nutrition is one of the MDGs goals. Also, improvement of nutritional problems is contained in the 2015-2019 RPJMN target to reduce the prevalence of malnutrition and malnutrition by $15 \%$. The prevalence of malnutrition and malnutrition among children under five, there are $3.4 \%$ of children with malnutrition, and $14.4 \%$ of malnutrition. The problem of malnutrition in children under five in Indonesia is a public health problem that falls into the high category (WHO indicator is known to be a malnutrition problem of $17.8 \%$ ). To overcome this problem, Indonesia has joined the Scaling Up Nutrition (SUN) movement. Movements with 27 other countries since 2011. In Indonesia, the movement is known as the National Movement for the Acceleration of Nutrition Improvement in the First Thousand Days of Life (1000 Hari Pertama Kehidupan / HPK Movement). The government fully supports it through Government Regulation Number 42 of 2013 concerning the National Movement for the Acceleration of Nutrition Improvement (Kemenkes RI 2017).

This movement is not a new initiative or new funding, but an effort to increase the effectiveness of various existing initiatives and programs or activities through support from the national leadership, priority setting, and program harmonization. Therefore, coordination and technical support, high-level advocacy, and cross-sectoral partnerships are needed to accelerate the target of improving community nutrition, which is expected to focus on improving nutrition in the first 1000 days of life (Hari Pertama Kehidupan / HPK).

The problem of nutrition is multi-dimensional, involving the health sector and involving sectors outside of health, such as economy, education, socioculture, and others. A malnourished person is considered healthy and does not live long because he/she will be susceptible to dangerous infectious diseases. To increase the level of public health, it is necessary to make efforts to improve individual nutrition and community nutrition, to improve the quality of nutrition as intended by improving food consumption patterns, improving nutrition awareness behaviour, increasing access, and quality of nutrition 
Vol.6, No.2, 2020

Doi: https://doi.org/10.24198/cosmogov.v6i2.28541

http:/jurnal.unpad.ac.id/cosmogov/index

services under advances in science and technology.

Subang Regency is one of the city in West Java that carries out this nutrition improvement program as regulated in Regent Regulation No. 14C2 of 2008 concerning Main Duties and Functions of the Subang Regency Health Service Article 21. Nutritional problems are also still found in Subang Regency, especially malnutrition and nutrition (Yuhana, 2019). less in toddlers. In 2017, the number of malnourished children under five was $4.64 \%$ out of a total of 94,980 toddlers spread across 30 Districts in Subang Regency. Most cases of malnutrition are in Subang Regency, which is spread across eight sub-districts, namely 454 under-five. In the Cikalapa Community Health Centre's working area, namely the Soklat, Parung, Pasirkareumbi, and Wanareja villages, 218 toddlers are malnourished and severely malnourished (Yuhana, 2019). Meanwhile, in the Sukarahayu Community Health Centre's working area, namely the Karanganyar, Dangdeur, Sukamelang, and Cigadung villages, there were 244 children under five (Yuhana, 2019). As an example of this data, it can be seen that nutritional problems are still found in the Community Health Centre Sukarahayu. The number tends to increase, namely in 2016 as many as 209, and in 2017 as many as 244 babies and toddlers. Of that number, $70 \%$ of sufferers were accompanied by comorbidities (Yuhana, 2019). Due to the disease, toddlers have difficulty eating regularly. While the other $30 \%$ are due to wrong parenting, such parenting impacts irregular nutritional intake (Yuhana, 2019).
Agustino (2008) defines policy as a series of actions or activities proposed by a person, group, or government in a certain environment where there are obstacles difficulties and opportunities for implementing the proposed policy to achieve certain goals (Yuhana, 2019). This opinion also shows that the idea of a policy involving actors who have goals and objectives is the most important part of the policy definition because after all policies must show what is being done rather than what is attempted in activities on a problem (Denhardt, Denhardt, \& Blanc, 2014).

Solichin Abdul Wahab argued that the term policy itself is still subject to disagreement and is an expert debate arena. So to understand the term policy, Solichin (Wahab, 2008) provides some guidelines as follows:

1. Policies must be distinguished from decisions.

2. Actual policy is not necessarily differentiated from the administration.

3. The policy covers behaviour and expectations.

4. The Policy includes neither action nor action.

5. Policies usually have a result to be achieved.

6. Every policy has specific goals or objectives, either explicit or implicit.

7. The Policy arises from a process that goes on overtime.

8. Policies include inter-organizational and intra-organizational relationships.

9. Public policy, although not exclusively, concerns the key roles of government agencies.

10. The policy is formulated or defined by suggestion. 
Vol.6, No.2, 2020

Doi: https://doi.org/10.24198/cosmogov.v6i2.28541 http://jurnal.unpad.ac.id/cosmogov/index

According to (Winarno, 2007) the term policy may be used broadly such as in "Indonesian Foreign Policy", "Japanese Economic Policy", and or it may also be used to become something more specific, such as if we said the government's policy on Debureaucratization and deregulation. However, both Solchin Abdul Wahab and Budi Winarno agree that this policy's terms are often used interchangeably with other terms such as program goals, decisions, laws, provisions, standards, proposals, and grand designs (Suhartono, 2009).

Winarno (2007) also states that policy should be understood as a series of activities that are more or less related to consequences for those concerned rather than as an independent decision. These two experts' opinion can at least explain that exchanging the term policy with a wrong decision because basically policy is understood as a direction or pattern of activity and not just a decision to do something (Chouinard \& Milley, 2015). Based on the opinions of various experts mentioned above, it can be concluded that policies are actions or activities that are intentionally carried out or not carried out by a person, group, or government in which there is an element of decision making an effort to choose between the various alternatives that exist to achieve certain goals and objectives.

\section{Creating Effectiveness as a Program}

Effectiveness comes from the word effective, which implies the achievement of success and achieving the goals that have been set. Effectiveness is always related to the relationship between the results expected and the results achieved. Popular scientific dictionaries define effectiveness as the appropriateness of use, use results, or supporting goals. (Gie, 2004) defines effectiveness as a condition that implies the occurrence of a desired effect or effect. The action is said to be effective if it causes consequences or achieves the intended purpose (Monirul, 2019). Measuring an organization's effectiveness, activity or program is not a very simple matter, because effectiveness can be assessed from various points of view and depends on who assesses and interprets it (Mongkol, 2011).

When viewed from a productivity point of view, a production manager understands that effectiveness means the quality and quantity (output) of goods and services (Negrea, Tarţa, \& Giurgiu, 2016).

Based on the effectiveness measure above, it can be seen that the measure of effectiveness is an effort to achieve goals through predetermined stages based on goal achievement, integration, and adaptation. Measurement of program effectiveness as stated by (Annas, 2017) namely:

Punctuality, the program that has been formulated must be implemented properly following the predetermined time. This is intended to produce the expected output and provide satisfaction to program recipients (Negrea et al., 2016).

Human resources who manage the program are a determining factor in the success of the program. In this case, the selection of human resources to implement the program needs to be done (Bozeman, 2002). The selection of human resources is based on criteria under the program to be implemented. This emphasizes the principle of "the right man on the right job". 
Vol.6, No.2, 2020

Doi: https://doi.org/10.24198/cosmogov.v6i2.28541 http:/jurnal.unpad.ac.id/cosmogov/index

Cooperation and communication need to be done in program implementation. In this context, the cooperation and communication between program administrators and program administrators with program targets (Kusnadi, 2019).

The correct distribution of funds is a working mechanism related to program financing. The available funds are used effectively and efficiently (Kusnadi, 2019).

No deviations, this emphasizes the absence of deviations in determining program targets. Monitoring and evaluation is the last criterion in measuring effectiveness (Kusnadi, 2019). This stage explains that an ongoing program must be monitored and evaluated to see the program's feedback (Yunindyawati, Sumarti, Adiwibowo, Hubbeis, \& Dinsyah, 2014).

Based on this description, the authors conclude that effective program measurement is carried out by starting from clear program formulation followed by processes that prioritize cooperation and communication between implementers, and the criteria for effective program measurement here state that for an effective program it is necessary to monitor and evaluate (Kusnadi, 2019; Yunindyawati et al., 2014). to find out the results or program feedback to determine whether the program can be continued or not.

\section{Managing Nutrition Improvement Program}

Based on SK. Menkes (Decree of Ministry of Health) No. 1277 / Menkes / SK / XI / 2007 Regarding the organization and work procedures of the Ministry of
Health, the strategy is taken to improve nutrition is through family empowerment in the health and nutrition sector, empowerment of officers and direct subsidies in the form of funds to purchase additional food and counselling on malnutrition. And pregnant women. The Nutrition Improvement Program is one of the main programs of the Community Health Centre, activities which include improving nutrition education, nutrition services, and counselling, overcoming protein-energy deficiency (Kurang Energi protein / KEP), iron nutrition anaemia, iodine deficiency disorders (IDD), vitamin A deficiency (kurang vitamin A / KVA), the condition of excess nutrients (obesity) and empowerment of efforts to improve family/community nutrition. The nutrition improvement program aims to improve the quality of nutrition and food consumption which has an impact on improving the state / nutritional status, especially the status of undernutrition and malnutrition, and maintaining a good nutritional status so that it can reduce the number of malnutrition diseases that are commonly suffered by low-income people (in rural and urban areas), especially for infants, toddlers, pregnant and lactating mothers.

This goal supports efforts to reduce infant mortality rate (IMR), under-five mortality (Angka Kematian Bayi / AKABA), and maternal mortality rate (MMR). To realize the optimal degree of public health, one of the elements of the national goal's general welfare. (Nasution, 1997) This program seeks to improve the community's nutritional condition in general by improving food consumption patterns that are increasingly diverse, 
Vol.6, No.2, 2020

Doi: https://doi.org/10.24198/cosmogov.v6i2.28541

http://jurnal.unpad.ac.id/cosmogov/index

balanced, and nutritional quality. This nutrition improvement program is regulated by the Minister of Health Regulation Number 23 of 2014 concerning Efforts to Improve Nutrition.

\section{METHOD}

In this study, researchers used a naturalistic/qualitative research method with a descriptive level of explanation. Qualitative research methods are research methods used to examine the conditions of natural objects (as opposed to experiments), where the researcher is the key instrument, the data collection technique is done by triangulation (combined), the data analysis is inductive, and the results of qualitative research are more emphasizes the meaning rather than (Creswell, 2009).

While the level of explanation or what is called the level of clarity, in this case how the variables under study can explain the object under study through the data collected (Pasolong, 2013), in this study using descriptive research, namely investigations carried out on independent variables or one independent variable or one variable, without making comparisons, or connecting with other variables (Pasolong, 2013).

The qualitative approach is deemed most appropriate to the objectives of this study The use of descriptive research methods (Sugiyono, 2014, 2017) with a qualitative approach is intended to make descriptions, descriptions systematically, factually, and accurately regarding the effectiveness of nutrition improvement programs for infants and toddlers in Subang Regency, a condition in the present and the relationship between the phenomena being investigated (Aisyahi, Utomo, \& Kasiwi, 2020; Sawir \& Hafid, 2020; Yuhana, 2019).

Qualitative research does not question the number of informants. However, it can depend on whether or not the selection of key informants is appropriate, and the complexity of the variety of social phenomena being studied (Sugiyono, 2014, 2017). Thus, the determination of informants is carried out using snowball sampling techniques, namely the process of determining informants based on previous informants without determining the exact number by digging up information related to the specified research topic (Sugiyono, 2014, 2017).

\section{RESULT AND DISCUSSION}

Assessment of program effectiveness needs to be carried out to find information about the extent to which the program's benefits and impacts have on program recipients, and this also determines whether or not a program can be continued (Mongkol, 2011). So that the assessment of effectiveness is critical. An effective program is if there are dimensions used to measure success (Purnamasari \& Ramdani, 2019).

Effectiveness is the relationship between output and input. In terms of effectiveness is how far the level of output, policies and procedures of the organization achieve the goals set. Effectiveness refers to success in terms of whether the targets have been achieved or not. If the nutrition improvement program results for infants and toddlers are closer to the target, it 
Vol.6, No.2, 2020

Doi: https://doi.org/10.24198/cosmogov.v6i2.28541

http://jurnal.unpad.ac.id/cosmogov/index

means that the program's effectiveness will be higher (Choi, 2016).

The description below discusses the results and discussion in research on the effectiveness of nutrition improvement program policies in Subang Regency according to (Annas, 2017) with several dimensions as follows: Punctuality, Human Resources, Work Mechanism, Cooperation and Communication, Correct Fund Distribution, No Deviation, Monitoring and Evaluation.

\section{Punctuality}

According to (Annas, 2017), punctuality is important in a program or policy's success or failure. For the program to be effective, it is necessary to implement the program according to the predetermined time. This dimension of punctuality is the initial stage of implementing the Nutrition Resilience Program in Subang Regency.

Punctuality can be seen through whether the program has been implemented according to the time, what form the program is given to the community and the obstacles in implementing it. Therefore, the researchers found several findings regarding implementing the Nutrition Resilience Program in Subang Regency related to the implementation time and the form of activities given to the community.

The following findings show that: "The nutrition improvement program for infants and toddlers has been implemented on time following the Annual Work Plan, Annual and Monthly Activity Implementation Plan. The activities carried out are weighing toddlers every month, socialization or counselling on Tuberculosis, Healthy Living Community Movement, Clean and Healthy Living Behavior, HIV / AIDS, providing additional food for malnutrition sufferers (baby and toddler) every three months, monitoring malnourished toddlers every once a month by visiting the toddler's house.

The Obstacles are there, for example, such as a parent who wrongly provides parenting. Some parents are embarrassed to come to the Posyandu (integrated service provided by the government for mother and kids) because their child suffers from malnutrition. It will hinder us from providing services ". (Interview results, September 4, 2018).

The results show that the implementation of this program has been running according to the predetermined time and is realized by various activities that support the program's objectives. However, several obstacles are felt by the community, especially those who have toddlers suffering from malnutrition, namely that they feel ashamed to bring their children to the posyandu and the distance from home to the posyandu which is quite far is also the reason. The concept of punctuality measures whether the program is implemented on time or not and needs to know how the activities are carried out and what the obstacles are.

Based on the results of the above interviews with several informants that the nutrition improvement program for infants and toddlers has been implemented according to the predetermined time, besides those activities to achieve the program objectives have been implemented 
Vol.6, No.2, 2020

Doi: https://doi.org/10.24198/cosmogov.v6i2.28541

http://jurnal.unpad.ac.id/cosmogov/index

properly, because the Subang Regency Health Office has implemented the same standard that differentiates it is how Puskesmas (Community Health Centers) run it.

\section{Human Resources as a Basis}

According to (Annas, 2017), a program is effective if managed by competent human resources and understands the whole program. Human resources are an important part of the nutrition improvement program for infants and toddlers because human resources run this program. Many negative views were formed due to community dissatisfaction with human resources, in this case, found in several Community Health Centre in carrying out their obligations. Therefore, human resources must be determined based on the management concept, namely "the right man on the right job".

Human resources who manage the program are required to be responsive in carrying out their duties and functions. According (Bozeman, 2002), responsiveness is related to the speed of response of services in providing services and capturing the aspirations that arise from customers/stakeholders. In short, the responsiveness here shows the alignment between programs and service activities with the needs and aspirations of the community.

Responsiveness is included as one of the performance indicators because responsiveness directly describes the ability of public organizations to carry out their mission and objectives, especially to meet the needs of society. Low responsiveness is indicated by a mismatch between services and community needs. This clearly shows the failure of organizations and programs in realizing the mission and goals of public organizations (Aisyahi et al., 2020). Organizations that have low responsiveness automatically have low performance as well. In this case, the researcher looks through the ability of employees to meet community needs.

Program implementers must be able to provide services, accurate information and carry out their duties as well as possible. In terms of human resources who run the program, it is competent and expert in nutrition and has received training and counselling.

They will be able to carry out the program well, and the community can benefit from it. It is also important to fulfil the availability of human resources so that there is a specialization of duties. Officers focus on their respective main tasks and functions, and the results they achieve are good. In the field findings related to human resources, information was obtained, stating that: "We are trying our best to provide optimal services and according to the community's needs. We will accommodate all aspirations and complaints from patients.

Meanwhile, the number of human resources in our Community Health Centre is sufficient, especially those who handle this program. Our Community Health Centre has two D3 nutritionists, who have received training in applied nutrition care, breastfeeding counsellors, and training in PMBA (feeding for children and toddlers) to be deemed qualified in implementing nutrition improvement programs for infants 
Vol.6, No.2, 2020

Doi: https://doi.org/10.24198/cosmogov.v6i2.28541

http://jurnal.unpad.ac.id/cosmogov/index

and toddlers. (Interview results, September 4, 2018).

Based on this information, it can be concluded that the officers have implemented nutrition improvement programs for infants and toddlers properly and following the existing regulations. It also provides convenience to patients in conveying their aspirations and complaints regarding the improvement of nutrition for infants and toddlers. This responsiveness attitude is essential to determine what policies are by the existing problems so that each of these problems can be resolved quickly and provide satisfaction to patients by meeting patients' needs. The author's research shows that human resources are not fast enough and responsive in following up on the aspirations and complaints of the community.

On the other hand, not all people understand the nutrition improvement program for infants and toddlers, so it becomes an obstacle to this program's effectiveness. The things above are very contrary to the theory put forward by (Annas, 2017). He explains that a program is effective if managed by competent human resources and understands the whole program. Therefore it is necessary to have responsiveness from officers and hold outreach activities to increase public knowledge about nutrition improvement programs for infants and toddlers so that the program's objectives can be realized.

\section{Struggle for Working Mechanism}

According to (Annas, 2017), work mechanisms are how program implementers take to achieve a goal. In other words, the working mechanism is a way of working or the totality of workflow that is taken in the implementation of a job in an organization. The working mechanism can be stated in a description or a flowchart of the Standard Operating Procedure (SOP). With SOPs, arrangements will be achieved so that there is no miscommunication, avoiding conflicts between functions, or even letting go of responsibilities, which can result in decreased organizational performance and the effectiveness of a program (Faedlulloh, 2018).

Every month a weighing activity is held in each sub-district to provide services to the community to improve nutrition, especially for infants and toddlers weighing every month accompanied by a village midwife and assisted by cadres. The village midwife assigned to the Posyandu is to check if there are complaints from the community and is also assigned to give immunizations to babies and toddlers at Posyandu. People who have babies or toddlers aged five years and under are given a Healthy Towards Card (Kartu Menuju Sehat / KMS) to help ensure that babies and toddlers are monitored for their nutritional status receive information in the form of knowledge about child development. So that if there are babies or toddlers whose nutritional status is poor, they will immediately be handled by the Community Health Centre.

The results also show that the handling of malnutrition cases in infants and toddlers has been implemented properly following the applicable SOP. Malnutrition cases are also not only handled by the Community Health Centre but also in collaboration with doctors, 
Vol.6, No.2, 2020

Doi: https://doi.org/10.24198/cosmogov.v6i2.28541

http://jurnal.unpad.ac.id/cosmogov/index

cadres, and the patient's parents. In this case, the working mechanism in carrying out the nutrition improvement program for infants and toddlers does not only involve the Community Health Centre because the experts must do several parts. The research results on nutrition security implementation procedures show that the procedures for implementing nutrition improvement programs for infants and toddlers have been implemented following the applicable SOP.

The officers have implemented the program under the Annual and Monthly Activity Implementation Plans. Moreover, this program has provided benefits to the community, especially those who have babies and toddlers. However, the followup process for babies and toddlers with chronic malnutrition is still quite long. Because the Community Health Centre is waiting for a decision from the Subang Regency Health Office for a referral to the hospital, the nutrition improvement program not only involves Community Health Centre internal parties but collaborates with cross-sectoral organizations. However, for the nutrition improvement program for infants and toddlers to be effective, the vision and mission of the Community Health Centre are achieved, it is necessary to improve mechanisms or services in terms of taking action against or referring patients suffering from chronic malnutrition.

\section{Engaging Community on Cooperation and Communication}

The importance of cooperation and communication in organizations is to achieve goals with satisfactory results and following what is expected together. An organizational leader benefits from other members of the organization, influencing, guiding, inspiring all of which can influence the motivation of the members of the organization in using positive ways (Kusnadi, 2019; Purnamasari \& Ramdani, 2019). If the leader cannot build good cooperation and communication, it will automatically hinder achieving goals or even result in performance that is not following what is desired (Irawan \& Faturahman, 2019).

Cooperation and communication cannot run independently, but these two things can make an organization or program run effectively when communication and cooperation can run simultaneously (Toni, 2018; Widiyanto, Hikmawan, \& Riswanda, 2019). In the organization there is a collaboration and communication that must be built between members of one another. Moreover, in running a program, there must be cooperation and communication built between one program implementer and another, and between program implementers and program recipients targets. Thus it can make an organization and an effective program.

According to (Annas, 2017) cooperation and communication, namely, the relationship between program implementers and the relationship between program implementers and program recipients, something that is said to be effective is when there are cooperation and communication between the parties involved.

The nutrition improvement program for infants and toddlers involves 
Vol.6, No.2, 2020

Doi: https://doi.org/10.24198/cosmogov.v6i2.28541

http://jurnal.unpad.ac.id/cosmogov/index

collaboration and communication between Community Health Centre and the target community, Community Health Centre with cross-programs and cooperation between Community Health Centre and cross-sectoral such as cadres, sub-districts and sub-districts. The results showed that in this program, the parties related to the nutrition handling had tried to establish good cooperation and communication until they visited the patient's house to monitor their progress. The health centres also provide information to the community about child development and the improvement of children's nutrition.

So that people can know and want to learn in providing the best for their children. Overall cooperation and communication in running this program have been effective. The forms of cooperation and communication that have been established have provided many benefits, one of which is community satisfaction. Community Health Centre in Sukarahayu prioritizes collaboration and communication to achieve the goals of the nutrition improvement program for infants and toddlers. Community Health Centre believes that without good cooperation and communication between the actors involved, a program or organization's goals will be difficult to achieve.

\section{Correct Fund Distribution}

One important aspect of running an organization or program is the correct distribution of funds. Funds or budgets are included in management resources that function to carry out management functions (Kiggundu, 1994). In an organization, funds are needed to finance an organization's organizational activities or finance work programs (Kiggundu, 1994). Because of the importance of the budget, it is necessary to monitor its use. According to (Annas, 2017), something is said to be effective if the available budget is used properly or in other words, it is used for the sustainability of the program according to predetermined goals.

The nutrition security fund in Subang Regency is intended to finance programs and treat malnourished toddlers. In this nutrition improvement program, the budget received by Community Health Centre is not in the form of cash but the form of additional food for toddlers such as biscuits, milk and vitamins provided by the Subang Regency Health Office.

So that in this nutrition improvement program, the correct distribution of funds is the distribution of additional food to the program targets, namely infants and toddlers from the age of 0-59 months 29 days whose body weight is $<-3$ Standard Deviation. To determine the correct distribution of funds in this program, the researchers conducted interviews with several Community Health Centre. One of them explained that "The nutrition improvement program for infants and toddlers is not funded in cash but the form of additional food (Makanan Tambahan / MT) such as biscuits, vitamins, and calcium milk. Moreover, the additional food is distributed to each posyandu in number according to the number of babies and toddlers under the red line or malnutrition. However, sometimes the number of additional food coming from the centre is insufficient so that babies and toddlers who have malnutrition are 
Vol.6, No.2, 2020

Doi: https://doi.org/10.24198/cosmogov.v6i2.28541

http://jurnal.unpad.ac.id/cosmogov/index

prioritized ". (Interview results, September 4, 2018).

The study results found a condition where the Community Health Centre staff had tried to give additional food to underweight babies and toddlers. However, in this case, the number of additional food provided by the Subang Regency Health Office is minimal, so babies and toddlers who are malnourished get the additional food first. This has resulted in the objectives of this nutrition improvement program not being achieved effectively. The Subang Regency government should pay attention to this by sufficient additional food available so that the nutrition improvement program for infants and toddlers is effective.

\section{The Absence of Deviation}

According to (Annas, 2017), something is effective if there are no deviations in all aspects. The absence of deviations here focuses on determining the target or recipient of the program that is right following the recipient's criteria. The targets here are infants and toddlers aged 59 months 29 days whose body weight is in the red line according to the weight/height indicator.

The nutrition improvement program for infants and toddlers is intended to improve the quality of nutrition and increase good and balanced nutrition. The Community Health Centre handles infants and toddlers who suffer from malnutrition or malnutrition. Undernutrition or malnutrition is an infant or toddler whose body weight is less than -3 standard deviation according to body weight/body height (BW / $\mathrm{BH}<-3 \mathrm{SD}$ ). From the results of interviews and direct observations in the field, the authors can conclude that the Community Health Centre is right in determining the target of the nutrition improvement program for infants and toddlers.

Everything has been done under applicable regulations. So that this program is already running well. Furthermore, the people who are the targets of this program have already felt the benefits. In connection with the absence of irregularities, the Community Health Centre always monitors and evaluates programs to identify and correct all forms of irregularities quickly. Furthermore, the Community Health Centre received suggestions and input regarding this nutrition improvement program. So when viewed in terms of deviation, it can be said that the nutrition improvement program for infants and toddlers at Sukarahayu Health Center has been effective.

\section{Monitoring and Evaluation as a Measurement}

Monitoring and evaluation are two integrated activities in the context of controlling a program (Chouinard \& Milley, 2015). Monitoring activities are more focused on activities that are being implemented. Monitoring is carried out by regularly digging for information based on certain indicators, to know whether the ongoing activities follow the agreed planning and procedures. Monitoring indicators include the essence of activities and targets set in program planning. If monitoring is carried out properly, it will be useful in ensuring that the implementation of activities remains on track according to 
Vol.6, No.2, 2020

Doi: https://doi.org/10.24198/cosmogov.v6i2.28541 http:/jurnal.unpad.ac.id/cosmogov/index

program guidelines and planning (Hikmawan, Hamid, Nurrohman, Ramadhan, \& Mayrudin, 2020). Also provides information to program managers in the event of obstacles and irregularities, and as input in conducting evaluations.

In principle, monitoring is carried out while the activities are ongoing to ensure the process's suitability and the results as planned or not. If deviation or inaction is found, it is immediately addressed to proceed according to plan and targets. So, the monitoring results become input for the benefit of the next process. At the same time, the evaluation is carried out at the end of the activity to determine the final results or achievements of the activity or program. The evaluation results are useful for planning the implementation of the same program at another time and place.

The statement according to Mrs Kader explained that Community Health Centre officers came to Posyandu to control whether this routine activity was carried out properly or not even though the schedule of visits to Posyandu was not routine because considering the number of Posyandu in the Community Health Centre work area was large, while Community Health Centre officers, especially the nutrition section, were limited.

Then, as a form of responsibility for posyandu officers, the weighing results are recorded and then submitted to the Community Health Centre as a form of monitoring and to determine further actions or policies. The result of an interview with a community who has a toddler suffering from malnutrition: "Yes, the Community Health Centre officer came to the house to check on my child's condition. Bring a scale, books, biscuits, milk and vitamins. So my child's condition is continuously monitored by the Community Health Centre even though I do not go to the Community Health Centre".

\section{CONCLUSION}

From the results of this study, the authors conclude that health centres conduct monitoring and evaluation to assess the extent to which the nutrition improvement program for infants and toddlers is running. Community Health Centre has tried to provide the best service for the community. By visiting the Posyandu, so that people feel close to the Community Health Centre. However, the community has not fully benefited from the Community Health Centre employees' presence coming to Posyandu because the time is limited. It is relatively short so that the community cannot consult about developing their children's nutrition.

The Nutrition Improvement Program Policy for Infants and Toddlers in Subang Regency has been running but is still effective. Several factors cause the ineffective nutrition improvement program policies in Subang Regency, including the following: Punctuality, nutrition improvement programs for infants and toddlers have been implemented on time. All activities have been carried out under the annual and monthly activity implementation plans. Furthermore, the benefits of this program have been felt by the community. Human resource factors, in the nutrition improvement program for infants and toddlers, have an important role in achieving predetermined goals. In 
Vol.6, No.2, 2020

Doi: https://doi.org/10.24198/cosmogov.v6i2.28541

http://jurnal.unpad.ac.id/cosmogov/index

Subang Regency, this program has been handled by competent employees and has received much training. So that employees can better understand the overall nutrition improvement program for infants and toddlers. Furthermore, the community also assessed that human resources' capacity and capacity who manage the program are good. In the working mechanism, the related agencies within the Community Health Centre and the Subang Regency Health Office have developed a mechanism or procedure that is used as a reference when implementing nutrition improvement programs for infants and toddlers.

One by one, the procedures have been done well. However, there are some public complaints that the procedure for referring patients with malnutrition to the hospital tends to take a long time. The child concerned can be handled late, cooperation and communication, in realizing this program, cannot be done by one party alone. Community Health Centre generally cooperate and communicate well with the community, across programs and sectors. Everything is going in harmony. In terms of the correct distribution of funds, the government's budget for this program is not in the form of cash but the form of additional food for toddlers, calcium milk, and vitamins. The number is still limited, so many children with BGM (below the red line) have not received the additional food.

Because Community Health Centre prioritizes children who suffer from malnutrition, there is no deviation. In determining the nutrition improvement program's target for infants and toddlers, several Community Health Centre has done it well. All children from 0 to 59 months, 29 days were weighed monthly and given additional food for underweight. Monitoring and evaluation, this stage has been carried out at several health centres to see the feedback from the nutrition improvement program for infants and toddlers. However, there are still complaints from the public regarding the service time; namely, the officers who monitor Posyandu activities are very short on time so that the community cannot freely consult about their children's condition. To achieve the food security program policy's success, it is necessary to consider various integrated factors.

\section{REFERENCES}

Agustino, Leo. (2008). Dasar-Dasar Kebijakan Publik. Alfabeta : Bandung.

Aisyahi, I. N. T., Utomo, E. P., \& Kasiwi, A. N. (2020). Analisis Kebijakan Ketahanan Pangan di Kabupaten Bantul. International Journal of Demos, 2(2), 151-162. https://doi.org/10.37950/ijd.v2i2.40 Abstract

Annas, Aswar. (2017). Interaksi Pengambilan Keputusan dan Evaluasi Kebijakan. Makassar: Celebes Media Perkasa.

Bozeman, B. (2002). Public-value failure: When efficient markets may not do. Public Administration Review. https://doi.org/10.1111/00333352.00165

Choi, J. W. (2016). New Public Management or Mismanagement? The Case of Public Service Agency of Indonesia. Journal of Government and Politics. https://doi.org/10.18196/jgp.2016.0 024

Chouinard, J. A., \& Milley, P. (2015). From new public management to new political governance: Implications for evaluation. 
Vol.6, No.2, 2020

Doi: https://doi.org/10.24198/cosmogov.v6i2.28541

http://jurnal.unpad.ac.id/cosmogov/index

\section{Canadian Journal of Program} Evaluation.

https://doi.org/10.3138/cjpe.30.1.1

Creswell. (, 2009). Research design: qualitative, quantitative and mixed approaches. Research Design. https://doi.org/10.2307/1523157

Denhardt, R. B., Denhardt, J. V, \& Blanc, T. A. (2014). Public administration, an action orientation. Public Administration. https://doi.org/10.4324/978131512 7705

Faedlulloh, D. (2018). BUMDes dan Kepemilikan Warga: Membangun Skema Organisasi Partisipatoris. Journal of Governance, 3(1), 1-17. https://doi.org/10.31506/jog.v3i1.3 035

Gie. Liang. (2004). Ensiklopedia Administrasi. Jakarta: PT Gunung Agung.

Hikmawan, M. D., Hamid, A., Nurrohman, B., Ramadhan, G., \& Mayrudin, Y. M. (2020). Collaborative Governance Model on Agricultural Business in Banten, Indonesia, 6(2), 176-201. https://doi.org/10.21776/ub.transfor mative.2020.006.02.3

Irawan, A., \& Faturahman, B. M. (2019). Public Services Motivation (PSM) in One-Stop Integrated Services in Merauke Regency. Journal of Governance, 4(2), 156-170. https://doi.org/10.31506/jog.v4i2.6 569

Kiggundu, M. N. (1994). Managing research institutions in developing countries: Test of a model. Public Administration and Development. https://doi.org/10.1002/pad.423014 0207

Kusnadi, I. H. (2019). Jejaring Collaborative Governance Pada Program Komunikasi , Informasi dan Edukasi ( KIE ) dalam Pencegahan HIV / AIDS di Kabupaten Subang. International Journal of Demos, 1(2), 204-231.

Laporan Tahun (2017). kegiatan tahunan Dinas Kesehatan Kabupaten Subang tahun.
Mongkol, K. (2011). The critical review of new public management model and its criticisms. Research Journal of Business Management. https://doi.org/10.3923/rjbm.2011. 35.43

Monirul, I. (2019). Does Good Governance Affect Globalization? A Case of Bangladesh. Journal of Governance, 4(2), 102-123. https://doi.org/http://dx.doi.org/10. 31506/jog.v4i2.5595 Does

Nasution, Amran, Mph. (1997). Perencanaan Kesehatan. Medan: USU Press.

Negrea, A., Tarţa, A. E., \& Giurgiu, A. (2016). Development of Human Resource Management in the $\mathrm{Eu}$ Context. Aspects of Evaluation and Dimensions. Annals of the University of Oradea, Economic Science Series.

Peraturan Bupati No 14C2 Tahun (2008) tentang Tugas Pokok dan Fungsi Dinas Kesehatan Kabupaten Subang.

Peraturan Pemerintah RI No 42 Tahun (2013). Gerakan Nasional Percepatan Perbaikan Gizi.

Purnamasari, H., \& Ramdani, R. (2019). Evaluasi Program Badan Usaha Milik Desa ( BUM DESA ) Oleh Dinas Pemberdayaan Masyarakat dan Desa di Kabupaten Karawang. International Journal of Demos, 1(1), 89-100.

Sawir, M., \& Hafid, S. (2020). Effectiveness of The Agriculture and Food Department in Developing The Food Security Sector in Yalimo Regency. Journal of Governance, 5(1), 105-122. https://doi.org/10.31506/jog.v5i1.7 814

Sugiyono. (2014). Metode Penelitian Kombinasi (Mixed Methods). Bandung: Alfabeta.

Sugiyono. (2017). Metode Kuantitatif, Kualitatif dan RND. Bandung: Alfabeta.

Toni, H. (2018). Potret Representasi Pengelolaan Goa Pindul (Studi Representasi Pokdawis Karya Wisata Tahun 2014). Journal of 
Vol.6, No.2, 2020

Doi: https://doi.org/10.24198/cosmogov.v6i2.28541

http://jurnal.unpad.ac.id/cosmogov/index

Governance, 3(1), 67-79. https://doi.org/10.31506/jog.v3i1.3 008

Wahab, A. Solichin (2008). Analisis Kebijaksaan dari formulasi ke implementasi kebijaksanaan negara. Jakarta : Bumi Aksara

Widiyanto, A., Hikmawan, M. D., \& Riswanda, R. (2019). Implementasi Rencana Aksi Nasional Bela Negara Berdasarkan Instruksi Presiden Nomor 7 Tahun 2018 Oleh Dewan Ketahanan Nasional Republik Indonesia. Journal of Social Politics and Governance, 1(2), 95-115.

Winarno, Budi. (2007). Kebijakan PublikTeori \& Proses. PT BUKU KITA: Jakarta.

Yuhana, K. (2019). Implementasi Kebijakan Ketahanan Pangan dan Gizi di Kabupaten Subang. International Journal of Demos, 1(2), 232-261.

Yunindyawati, Sumarti, T., Adiwibowo, S., Hubbeis, A. V. S., \& Dinsyah, H.-. (2014). Kontestasi Diskursus Ketahanan Pangan Dan Pembentukan Kuasa Pengetahuan Perempuan Pada Keluarga Petani Sawah Di Sumatera Selatan. Jurnal Komunitas, 6(1), 170-179. 